\title{
Entrepreneurial Decisions and Liquidity Constraints
}

Douglas Holtz-Eakin

Syracuse University

David Joulfaian

U.S. Department of the Treasury

Harvey S. Rosen

Princeton University

February 1992

We thank Esther Gray and Kathleen Staudt for their aid in preparing the manuscript. Bruce Meyer, Jonathan Skinner, and seminar participants at Syracuse University, Northwestem University, University of Chicago, University of Wisconsin, Columbia University, and the National Bureau of Economic Research provided valuable suggestions. The views in this paper do not necessarily represent the views of any of the institutions with which the authors are affiliated. 


\section{ENTREPRENEURIAL DECISIONS AND LIQUIDITY CONSTRAINTS}

\section{$\underline{\text { ABSTRACT }}$}

This paper analyzes the role of liquidity constraints in the formation of new entrepreneurial enterprises. The basic empirical strategy is to determine whether an individual's wealth affects the probability of becoming an entrepreneur, and the conditional anounts of depreciable assets and interest deductions, ceteris paribus. If so, liquidity constraints are likely to be present. To be successful, such a research strategy requires a measure of asset variation that is both precisely measured and exogenous to the entrepreneurial decision. Our data are uniquely well-suited for this purpose. The sample consists of the 1981 and 1985 federal tax returns of a group of people who received inheritances in 1982 and 1983, along with information on the size of those inheritances from a matched set of estate tax returns. Hence, we can examine how the exogenous receipt of capital affects the decision to become an entrepreneur and important financial characteristics. of new enterprises.

Our results suggest that the size of the inheritance has little effect on the probability of hecoming an entrepreneur, but that conditional on becoming an entrepreneur, the size of the inheritance has a statistically significant and quantitatively important effect on the amount of capital employed. The conditional elasticity is 0.45 . Thus, liquidity constraints matter, but not in the fashion suggested in some earlier investigations.

Douglas Holtz-Eakin Metropolitan Studies Program Syracuse University Syracuse. NY 13244 $315-443-9049$
David Joulfaian

Office of Tax Analysis U.S. Treasury

Washington, D.C. 20220 202-566-2511
Harvey S. Rosen Department of Economics Princeton University Princeton, NJ 08544 609-258-4022 


\section{INTRODUCTION}

Testifying several years ago at a congressional hearing on "the entrepreneurial spirit in America," Wisconsin's Senator Robert Kasten said of entrepreneurs: "They create new jobs. They provide new competition to existing businesses. They help to improve product quality, help to reduce prices, add new goods and services never before thought of, advance new technologies, America's competitive stance." 1 This statement is typical of the widespread view that entrepreneurial enterprises are valuable sources of innovation, employment, and economic dynamism. Consequently, public policymakers have sought to develop strategies for encouraging entrepreneurship. Many of these strategies focus on entrepreneurs' need for "seed money," building on the notion that people who want to start new businesses are often frustrated by lack of access to capital markets. If money could somehow be channelled to entrepreneurs, the argument goes, the extent of entrepreneurship could be increased. Thus, for example, some have argued that pension funds for state and local govemment employees should try to invest in entrepreneurial concerns. And of course, the very existence of the federal Small Business Administration is premised on the idea that potential entrepreneurs cannot obtain start-up money, so that grants and subsidies will increase the supply of entrepreneurship.

A substantial theoretical literature explains how credit rationing can emerge even in a world in which all agents are optimizing. ${ }^{2}$ Hence, economists have taken seriously the hypothesis that capital market constraints may be an important determinant of the decision to become an entrepreneur. As noted below, a number of careful econometric studies have tested this hypothesis, producing somewhat mixed results. This paper brings a unique set of data to bear on this question. The sample consists of the 1981 and 1985 federal individual 
income tax returns of a group of people who received inheritances in 1982 and 1983, along with information about the size of their inheritances. Any individual who is a sole proprietor must file a "Schedule C" with his or her tax retum. Hence, we can examine who became a sole proprietor between 1981 and 1985 , and the extent to which the decision was influenced by the size of the inheritance. As suggested by Blanchflower and Oswald [1990], the receipt of an inheritance is about as close to a natural experiment as one is likely to get in this area. If owning a substantial stock of capital is important to starting a business, then those who receive a lump sum of capital should have a higher probability of doing so, ceteris paribus.

Another advantage of our tax return data is that they allow examination of some seldom explored questions relating to the impact of liquidity constraints on the operation of new entrepreneurial enterprises. Specifically, we can investigate whether liquidity constraints influence the amount of capital invested in the firm and the extent to which that capital is financed by borrowing.

Section 2 provides a brief discussion of previous empirical work on the entrepreneurship decision, with an emphasis on the treatment of liquidity issues. Section 3 specifies the models to be estimated. In Section 4 we discuss data and econometric issues, and we present the results in Section 5 . We find that liquidity constraints do not have a significant effect on the decision to become an entrepreneur. However, conditional on becoming an entrepreneur, liquidity constraints have a statistically significant and quantitatively important impact on the amount of capital employed by the new firm, and the amount of borrowing done by the owner. Section 6 concludes with a summary and suggestions for future research. 


\section{EARLIER STUDIES ${ }^{3}$}

Empirical work on the impact of liquidity constraints on the decision to become an entrepreneur has been guided by apparently straightforward logic: Some initial capital is required for setting up a new enterprise. If individuals are price takers in the credit market, then the ability to obtain capital, and hence, the decision to start the enterprise, should be independent of the prospective entrepreneur's personal financial position. An associated empirical strategy is to use cross-sectional data to estimate a probit or logit equation for the probability of self-employment, including some measure of the individual's assets among the explanatory variables. ${ }^{4}$ For example, Meyer [1990] estimated logit equations using 1984 data from the Survey of Income and Program Participation (SIPP) and found that the probability of being self-employed increases with an individual's net worth, ceteris paribus. Similarly, Blanchflower and Oswald [1990] employed probit analysis to analyze the incidence of self-employment among a cross-section of British males who were 23 years of age in 1981. The survey used by Blanchflower and Oswald contained a question about the size of any gifts or inheritances that the respondent might ever have received, and the response was included as a right-hand-side variable. The results suggested that such transfers are statistically significant and quantitatively important: a person who received $\mathscr{L} 5,000$ was twice as likely to be set up in business than a person who had received nothing, ceteris paribus.

Several papers have suggested that cross-sectional analysis of self-employment decisions is not the most suitable method for examining the possible role of liquidity constraints. Meyer [1990] argued that a superior approach is to use longitudinal data to examine transitions into entrepreneurship. As noted in the introduction, the policy motivation for this line of research is to determine which policies might be efficacious in encouraging 
entrepreneurship. This suggests that the transition process is the proper focus of attention. From a technical viewpoint, examining transitions has the advantage of using explanatory variables that are dated prior to the time the decision is taken. This reduces the likelihood that the explanatory variables are consequences of the decision to become an entrepreneur rather than its determinants. Timing issues are particularly cogent in investigations of the relationship between self-employment and personal assets. In a cross-section, does a positive sign on an assets variable suggest that people with more wealth become entrepreneurs, or that entrepreneurs accumulate more wealth? Of course, even using wealth accumulated prior to the time of the entrepreneurship decision may not eliminate entirely the problem of endogeneity; individuals may accumulate wealth in anticipation of going into business.

Using the U.S. National Longitudinal Survey for Young Men, Evans and Leighton [1989] found that the probability of becoming self-employed between 1976 and 1981 increased with net worth, as measured by assets. Evans and Jovanovic [1989] used data from the same survey to analyze transitions between 1976 and 1978 . The coefficient on their assets variable (net family assets as reported in 1976) was positive and statistically significant, pointing to the presence of liquidity constraints. Meyer [1990] used SIPP data to examine transitions from wage-eaming to self-employment between 1984 and 1985 . He found that from a statistical point of view, assets were significant, but their quantitative impact was quite minor. In his sample, 0.019 of the individuals made the transition to self-employment. Meyer's estimates implied that giving a person an additional $\$ 100,000$ would raise the transition rate only by $0.00017^{5}$

Although the impact of personal wealth differs across studies, the following empirical regularities have emerged. At a given point in time, self-employed individuals have higher 
assets than wage-earners, ceteris paribus. Looking at transitions from wage-eaming into selfemployment, initial assets also have a positive effect, but the quantitative importance of this effect is controversial. Some murkiness, however, is imparted to the results on transitions because individuals may save in order to start a business, perhaps inducing an upward bias in the estimated impact of assets.

Finally, it is noteworthy that the explicit or implicit theoretical models behind all of the empirical analyses that we have discussed assume that new enterprises require some capital. This requirement generates the link between liquidity constraints and the decision to become an entrepreneur. In fact, our data suggest that over one-half of all new enterprises have no depreciable assets. Thus, understanding the role of personal wealth in entrepreneurship requires that we view the transition from wage-eaming and the demand for capital by new firms as related but distinct phenomena.

\section{THE MODEL}

Our model focuses on the new entrepreneur's demand for capital borrowing and how it interacts with the decision to become an entrepreneur. The model is very much in the spirit of Evans and Jovanovic [1989], although there are some significant differences that we point out as the argument proceeds. To begin, assume that individual $i$ has utility function $U\left(Y_{i} ; Z_{i}\right)$, where $Y_{i}$ is income and $Z_{i}$ is a vector of personal characteristics that may influence the marginal utility of income, which is assumed to be constant for each individual ${ }^{6}$ The individual's earnings potential as a wage-eamer is $w_{i}$, an unobserved variable that has some distribution across individuals, and whose value is not revealed to the individual until after 
the decision to become a wage-eamer. If the individual's assets are $A_{i}$ and the net rate of return is $r$, then his income as a wage-earner is $w_{i}+r A_{i}$.

If the individual becomes an entrepreneur, his gross earnings are $\theta_{i} f\left(k_{i}\right) \varepsilon$, where $f(\cdot)$ is a production function whose only input is capital $\left(k_{i}\right), \theta_{i}$ is the individual's unobserved ability as an entrepreneur and $\varepsilon$ is a random component to the production process. As with $w_{i}, \theta_{i}$ has a distribution across individuals and is not revealed to the individual until after the decision to become an entrepreneur. We assume that the logarithm of $\varepsilon$ has mean zero and finite variance, and that $\varepsilon$ is independent of the $\theta_{i} \cdot{ }^{7}$ One can think of $f(\cdot)$ as embodying a fixed amount of labor input, i.e., the model ignores issues surrounding the allocation of time between labor and leisure. We assume that $f(0)>0$-- the firm can produce output even in the absence of capital input. In contrast, Evans and Jovanovic assume $f(0)=0$. As noted below, in Meyer's [1990] and our own data sets, a substantial number of entrepreneurial enterprises appear to have no capital whatsoever. Hence, $f(0)>0$ appears to be more realistic than $f(0)=0 .^{8}$ The distinction is important in the rest of the argument.

Recalling that $A_{i}$ is personal assets, $A_{i}-k_{i}$ is available to earn capital income, and the individual's net income as an entrepreneur is $\theta_{i} f\left(k_{i}\right) \varepsilon+r\left(A_{i}-k_{i}\right)$. By definition, $k_{i}-A_{i}$ is the amount of capital financed by borrowing. We assume that the amount of capital invested in the enterprise is bounded by a liquidity constraint generated by the financial markets, and the size of the constraint depends on the individual's net assets:

$$
k_{i} \leq l\left(A_{i}\right)
$$

This specification is less restrictive than that of Evans and Jovanovic, who, in order to make the estimation of their structural model tractable, assumed that borrowing is restricted by a fixed proportion of $A_{i}{ }^{9}$ 
With this setup, if the individual becomes an entrepreneur, his optimal amount of capital is the solution to the problem

$$
\operatorname{Max} E\left\{\theta_{i} f\left(k_{i}\right) \varepsilon+r\left(A_{i}-k_{i}\right)+\lambda_{i}\left[l\left(A_{i}\right)-k_{i}\right]\right\},
$$

where $\lambda_{i}$ is the Lagrange multiplier associated with the liquidity constraint and $E|\cdot|$ denotes the expected value. Three cases are possible. In the first,

$$
\begin{aligned}
\theta_{i} f^{\prime}\left(k_{i}^{*}\right) & =r \\
\lambda_{i} & =0,
\end{aligned}
$$

$k_{i}^{*}>0$, and $k_{i}^{*}<l\left(A_{i}\right)$; where $k_{i}^{*}$ denotes the optimal level of capital for the new firm. ${ }^{10}$

The enterprise employs capital, and the liquidity constraint is not binding. In the second case

$$
\begin{aligned}
\theta_{i} f^{\prime}(0) & <r \\
\lambda_{i} & =0 .
\end{aligned}
$$

Here, the marginal product of capital is less than the interest rate, and $k_{i}^{*}=0$ regardless of the liquidity constraint.

In the final case the liquidity constraint is binding, so

$$
\begin{aligned}
\boldsymbol{\theta}_{i} f^{\prime}(k) & >r \\
\lambda_{i} & >0
\end{aligned}
$$

As a result $k_{i}^{*}=l\left(A_{i}\right)$.

It is useful to restate these results as the answers to two questions. First, how is it determined whether an entrepreneurial enterprise has any capital? The answer is that capital is demanded only if an individual's entrepreneurial ability is sufficient to make it profitable. That is

$$
k_{i}^{*}=0 \text { whenever } \theta_{i} \leq \frac{r}{f^{\prime}(0)}
$$

and 


$$
k_{i}^{*}>0 \text { whenever } \theta_{i}>\frac{r}{f^{\prime}(0)}
$$

Expressions (3.6) and (3.7) highlight the crucial role of the individual's unobservable entrepreneurial ability $\theta_{i}$ in determining whether or not he or she demands capital. The second question is, how much capital is purchased, conditional on the quantity being positive? The answer here also depends on $\theta_{i}$, because expressions (3.3) to (3.5) together imply that $^{11}$

$$
k_{i}^{*}=g\left(A_{i}, \theta_{i}\right)
$$

The impact on $k_{i}^{*}$ of changing $A_{i}$ depends on whether the firm is liquidity constrained. If so, $k_{i}^{*}=l\left(A_{i}\right)$, leading directly to:

$$
\frac{d k_{i}^{*}}{d A_{i}}=l^{\prime}\left(A_{i}\right)>0
$$

Otherwise,

$$
\frac{d k_{i}^{*}}{d A_{i}}=0
$$

So far, our focus has been on the acquisition of capital. The model also can be used to analyze the firm's borrowing decisions. We focus on interest payments associated with borrowing for the entrepreneurial enterprise, rather than borrowing per se because our data set contains information on the former. The entrepreneur's optimal interest payments, $I_{i}^{*}$, are equal to $r\left(k_{i}^{*}-A_{i}\right)$. If the firm is constrained, the change in interest payments with respect to a change in the entrepreneur's assets is

$$
\frac{d I_{i}^{*}}{d A_{i}}=r\left(\frac{d k_{i}^{*}}{d A_{i}}-1\right)=r\left(l^{\prime}\left(A_{i}\right)-1\right)
$$


Provided that $l^{\prime}\left(A_{i}\right)>1, \frac{d I_{i}^{*}}{d A_{i}}>0$. For an unconstrained firm, $\frac{d k_{i}^{*}}{d A_{i}}=0$, and

$$
\frac{d I_{i}^{*}}{d A_{i}}=-r<0
$$

Thus, the direction of the impact of an increase in the entrepreneur's assets on his or her borrowing depends on whether or not the firm is constrained. It is also informative to compare expression (3.9) for $\frac{d k_{i}^{*}}{d A_{i}}$ with expression (3.11). The comparison suggests that for a capital constrained firm, the incremental impact of another dollar of assets on capital expenditures exceeds the impact on interest payments.

To summarize our comparative statics results with respect to the effects on capital $\left(k_{i}^{*}\right)$ and interest payments $\left(I_{i}^{*}\right)$ when the entrepreneur's assets $\left(A_{i}\right)$ increase: conditional on being an entrepreneur, $\frac{d k_{i}^{*}}{d A_{i}}$ is positive if the firm is liquidity constrained, and zero otherwise. Also conditional on being an entrepreneur, $\frac{d I_{i}^{*}}{d A_{i}}$ is positive if the firm is liquidity constrained, and negative otherwise. Finally, for a constrained firm, $\frac{d k_{i}^{*}}{d A_{i}}>\frac{d l_{i}^{*}}{d A_{i}}$.

So far we have discussed behavior conditional on being an entrepreneur; we turn now to the decision of whether to become an entrepreneur itself. ${ }^{12}$ The decision is based on a comparison of expected utilities in the two modes. ${ }^{13}$ The individual will opt for entrepreneurship if

$$
E\left\{U\left(\left[\theta_{i} f\left(k_{i}^{*}\right)+r\left(A_{i}-k_{i}^{*}\right)\right] ; Z_{i}\right)\right\}>E\left\{U\left(\left[w_{i}+r A_{i}\right] ; Z_{i}\right)\right\}
$$

Substituting equation (3.8) into (3.13) and letting $V(\cdot)$ denote the composite function yields:

$$
E\left\{V\left(A_{i}, \theta_{i} ; Z_{i}\right)\right)>E\left\{U\left(\left[w_{i}+r A_{i}\right] ; Z_{i}\right)\right\}
$$

Examination of inequality (3.14) makes it clear that the decision to become an entrepreneur depends on a combination of both $\theta_{i}$ and $w_{i}$. In addition, it will reflect $A_{i}$, and the vector $Z_{i}$ that determines the shape of the individual's utility function. That is, the 
decision depends upon relative ability in each mode, resources, and tastes. Note that the decision to become an entrepreneur and the capital acquisition decision are inextricably linked, as both are driven in part by the variable $\theta_{i}$. This joint role for unobservable entrepreneurial ability will guide the development of our econometric strategy.

We turn now to a discussion of the variables included in $Z_{i}$, the vector of personal attributes that affect the relative utilities of operating in a wage-eamer versus an entrepreneurial mode.

Age. An individual's age may be correlated with his attitudes toward risk and toward the various nonpecuniary aspects of being an entrepreneur. In addition, age is related to the individual's years of labor market experience, and hence his or her human capital. While an explicit measure of experience would be preferable, no such measure is included in our data. Following the practice in earlier studies, we also include a quadratic term in age. In addition, work in the salaried sector may become relatively less attractive at retirement age, so we include a dichotomous variable that takes a value of 1 if the individual is over 65 years old, and 0 otherwise.

Marital status and number of children. These two demographic variables may affect tastes for working in the various modes, although the direction of their effect is not clear. Having to support a family, for example, might make a person less likely to undertake risky ventures. At the same time, however, the presence of family support might make it easier to get a new business going.

Employment status of donor. Lentz and Laband [1990] have found that the probability that an individual is a self-employed proprietor increases if his parents were also selfemployed proprietors, in part because children acquire informal business experience from 
their parents. Of course, tax returns do not ask about parents' lifetime occupations.

However, we were able to obtain the 1981 personal income tax returns of the individuals who made the bequests, and determined whether they included a Schedule $\mathrm{C}$. We include on the right-hand side a dichotomous variable indicating whether or not the decedent filed a Schedule C. Assuming that this effect depends on the closeness of the relationship between the decedent and the beneficiary, we also include a variable that interacts the decedent's Schedule $\mathrm{C}$ variable with an indicator for whether the recipient is a son or a daughter. We anticipate that these two "taste" variables will raise the probability of self-employment on the assumption that children (and other relatives) of entrepreneurs are more likely to have entrepreneurial human capital imparted to them. A reasonable question is whether these variables are in some sense influencing the budget constraint--children of entrepreneurs may be more likely to inherit businesses. However, as noted below, we have a separate variable that indicates whether the estate included a business.

In addition to personal attributes, previous studies have generally included some measure of earnings prior to the transition to entrepreneurship, and so do we. However, 1981 tax retums have data on family earnings only, which complicates the interpretation of this variable. If only one person in the family participates in the labor market, earnings may be viewed as representing the opportunity cost of entering entrepreneurship. In this case, high eamings would tend to depress the probability of becoming an entrepreneur, ceteris paribus. However, if both spouses work in the market, then high earnings may be indicative of the fact that the family can expect a regular income flow even if an entrepreneurial venture does not do well. In this event, high earnings would tend to increase the probability of becoming an entrepreneur. ${ }^{14}$ 
A word is in order about several conventional variables that we are not able to include in the $Z$ vector because they are absent from tax retums. First, we have no information on race, and there is some evidence that the process generating self-employment decisions is different for blacks and whites (Meyer [1990]). As several studies have shown, blacks have much less wealth than whites (see Blau and Graham [1990]), and it is therefore unlikely that many blacks receive substantial inheritances. For this reason, we believe that there are few, if any, blacks in our sample, and the potential problems from pooling together blacks and whites are minimal.

Another variable that might plausibly be included is years of education, which could affect both eamings capacity and attitudes toward risk. Years of education has been employed in virtually every study. Interestingly, Fuchs [1982], Evans and Leighton [1989], Evans and Jovanovich [1989] and Rees and Shah [1986] have all found that it is insignificant as a determinant of the self-employment decision. While this verdict is not unanimous (see Meyer [1990]), the evidence suggests that our forced omission of education may not be doing much harm to the analysis, although it likely muddles the interpretation of the eamings variable.

We turn next to the measurement of $A_{i}$, the individual's assets. Our data provide different amounts of information on various assets. Dividends and interest are reported on tax returns; with the assumptions on capitalization rates discussed in the next section, we can impute the stock of assets that generated these flows and include it in the analysis. ${ }^{15}$ We are unable to make any meaningful imputations on the value of owner-occupied housing, but on the basis of information on mortgage interest and property tax deductions, we can create a dichotomous variable indicating whether or not the family owns a home. The centerpiece of 
our analysis is the amount of the inheritance. As noted above, we wish to view the coefficient on the inheritance as telling us something about the presence or absence of liquidity constraints. However, if bequests consist of businesses, then there may be a positive correlation between the likelihood of setting up a business and the size of an inheritance that has nothing to do with liquidity constraints. To allow for this possibility, we include a dichotomous variable that is equal to one if the estate included nonliquid assets such as a business.

\section{DATA AND ECONOMETRIC ISSUES}

\subsection{Preliminary Considerations}

Our data are rather different from those that have been used in earlier studies, which have relied on surveys designed principally to provide information about individuals' labor market status. In contrast, we have tax retum data. The use of such data gives rise to several issues.

The first relates to a problem faced by every empirical researcher in this area -making the notion of entrepreneurship operational. How do we know who is an entrepreneur? In the nonstatistical literature on this topic, entrepreneurs are characterized in terms of their daring, risk-taking, animal spirits, and so on:

"To act with confidence beyond the range of familiar beacons and to overcome that [social] resistance requires aptitudes that are present in only a small fraction of the population and that define the entrepreneurial type..." (Schumpeter [1942], p. 132)

Those who do statistical work must settle for observable (and hence, more prosaic) criteria for classifying someone as an entrepreneur. In previous studies, the key criterion has been whether the individual classifies him or herself as being primarily self-employed, a 
natural choice if the data set focuses on labor market issues. With tax return data, the most sensible proxy for "entrepreneurship" is the presence of a Schedule C in the tax return. ${ }^{16}$

One could argue that the presence of Schedule $\mathrm{C}$ is more indicative of tax sheltering activity than entrepreneurial activity. For example, some economists may report their consulting income and honoraria on Schedule $\mathrm{C}$ solely in order to be eligible for certain deductions. However, data from the 1985 Statistics of Income indicate that such personal service activities are undertaken by only a small proportion of Schedule C filers, about 16 percent. ${ }^{17}$ And surely at least some of these activities reflect classical entrepreneurial behavior of the sort described by Schumpeter.

Several algorithms for identifying which Schedule C filers are "serious" entrepreneurs have been suggested to us. One possibility is that net receipts be above some threshold level. But many start-up enterprises have both low gross receipts and high expenses. Another possibility is that the ratio of Schedule $C$ income to earned income be above some threshold. But as already suggested, "serious" entrepreneurs can have low or negative net income. Another version of this idea is to identify people whose earned income falls by more than a threshold percentage when they make the transition to filing Schedule C. However, for married couples, one spouse might enter the labor market as the other withdraws to work on the entrepreneurial enterprise. If so, family earnings (which is all we can observe), might not change very much. Even absent these complications, at the start of his or her career as a "serious" entrepreneur, an individual may not be ready to quit his or her job. ${ }^{18}$

We conclude that trying to weed out ersatz entrepreneurs from the population of Schedule $\mathrm{C}$ filers is not likely to be terribly fruitful. These concerns notwithstanding, in 
Section 5 below we experiment a bit with the criteria for being an entrepreneur, and find that they have no serious impact on our substantive results.

The second issue that arises when using tax retum data concerns the measurement of assets prior to becoming an entrepreneur, which is central to the examination of the impact of liquidity constraints on behavior. Conventional data sources rely on self-reported values of the stocks of various assets. The possible biases in such measures are well-known (see, for example, Avery, Elliehausen, and Kennickell [1988]). Tax return data do not contain information on stocks of assets per se. However, one can impute the value of a household's assets by capitalizing the flows of unearned income, a procedure that has been followed in earlier studies in a variety of contexts. (See, for example, Skinner and Feenberg [1990].) In addition, from the matched estate tax retums (Form 706, page 2), we have information on inheritances received after the first income tax retum (in 1981) and before the second return (in 1985). (The matching process is described below.) As stressed above, inheritances are more likely to be exogenous than conventional measures of assets, and hence provide a better variable for use in examining the role of liquidity constraints. ${ }^{19}$ Inheritance information from estate tax data has a second advantage: as Menchik [1988] has persuasively argued, administrative bequest records are likely to contain more accurate information than either selfreported or imputed measures.

A third issue concems various attributes of new entrepreneurial enterprises that can be investigated using the data. Previous studies have been able to ask virtually only one question relating to liquidity constraints: "Does the magnitude of an individual's assets affect the probability that he or she will become an entrepreneur?" This is an important question, which is also investigated herein. However, as our theoretical model suggests, liquidity 
constraints might have little impact on whether someone sets up a firm, but at the same time, they might have an important effect on the amount of capital acquired for the new firm and the amount of its borrowing. Schedule $\mathrm{C}$ has information on depreciation allowances and on interest deductions that can be used to investigate these questions. It also would have been interesting to see if liquidity constraints had a differential impact by type of enterprise.

Unfortunately, the "principal business code" from schedule C was not included in our data, so we were unable to categorize the firms by line of business.

A final issue concems the representativeness of the data set. The sample consists only of individuals who received inheritances from substantial estates. Such individuals tend to have very high pre-inheritance incomes. The mean 1981 Adjusted Gross Income per retum in our sample is $\$ 31,700$, about $\$ 12,000$ above the mean for all tax filers. Clearly, such individuals are not typical, and we make no claims that our results apply to the population as a whole. However, the results do allow us, in effect, to bound the importance of liquidity constraints. If anyone has good access to capital markets, it should be such high income individuals. To the extent that their decision-making is affected by liquidity constraints, it is likely that capital market constraints will be at least as important for lower income individuals.

Construction of our data set began with an Internal Revenue Service (IRS) sample of estate tax records. The IRS selected a one percent random sample of estate tax returns of people who died in 1982 and whose estate tax returns were filed in 1982 and 1983 . Returns with total assets over one million dollars were selected at a 100 percent rate. The sample included over $\mathbf{8 , 5 0 0}$ individuals with gross estates over $\$ 300,000$. 
The next step was to match the estate tax returns with the decedents' personal income $\operatorname{tax}$ retums for 1980 through 1982, and with the beneficiaries' personal income tax returns for 1980 through 1982 and 1985 . We dropped some observations because of the inability to make matches, missing data, etc. As noted above, our focus is on transitions to entrepreneurship between 1981 and $1985 .^{20}$ The number of observations with usable information for these two years was 7,036. Of these, 5,910 were not sole proprietors in 1981 ; these observations comprise the data used to analyze the transition into sole-

proprietorship. ${ }^{21}$ Thus, about 16 percent of the initial sample consists of sole proprietors. This is higher than the incidence of entrepreneurship from other samples. ${ }^{22}$ For example, according to Meyer [1990], 1980 census data indicate a self-employment rate of 9 percent, and the Survey of Income and Program Participation suggests a rate of 11.7 percent (including side businesses). As noted above, our sample has higher mean income than the population as a whole. In light of earlier findings of a positive cross-sectional correlation between income and entrepreneurship, it is no surprise that our sample has a relatively high incidence of entrepreneurship.

\subsection{Statistical Summary of the Data}

We now turn to a statistical description of the sample in 1981. The three columns of Table 4.1 show the means and standard deviations of the key variables for (1) the entire sample; (2) those who filed Schedule C; and (3) those who did not file Schedule C. The table indicates that in 1981 , the average age in the sample was 41.5 years, exactly the same as Gale and Scholz's [1991] figure for the average age for people who receive inheritances. $^{23}$ Those who filed a Schedule $C$ in 1981 are about 2 years older than their 
wage-eamer counterparts, consistent with the cross-sectional results of Meyer [1990] and Rees and Shah [1986], who found a positive relationship between entrepreneurship and age. Entrepreneurs are more likely than wage-eamers to be married and to have children, again consistent with cross-sectional correlations from some earlier studies. (See Meyer [1990] and Evans and Jovanovic [1989]. $)^{24}$ Returns with a Schedule C reported lower wage and salary earnings than those without it. Our data do not allow us to determine the extent to which this is due to less time spent at wage-earning as opposed to a lower hourly wage rate. ${ }^{25}$

Liquid assets were estimated by capitalizing interest receipts using a rate of return of 10 percent, and dividends using a rate of retum of 5 percent. (See Skinner and Feenberg [1990].) Clearly, such a measure of liquid assets is only a rough approximation to the true value. In contrast, the inheritance variable is based on administrative records and quite accurately measured. Hence, in the econometric analysis, it is the variable upon which we focus when trying to gauge the impact of assets on various decisions.

The mean inheritance in the sample is $\$ 119,000$. The range of this variable is wide; some donees received bequests of as little as $\$ 100$, while the maximum is $\$ 2.8$ million. The inheritances received by those filing Schedule $\mathrm{C}$ are also higher than those who are wageeamers, a phenomenon that may be linked to the findings at the bottom of the table.

Specifically, the means of DC (which equals one if the donor filed a Schedule C), and DC's interaction with the kinship variable, suggest that Schedule C filers are more likely to receive bequests from decedents who themselves filed Schedule C. To the extent that donors who filed Schedule $\mathrm{C}$ had larger lifetime incomes and estates, it then follows that the donees with Schedule $\mathrm{C}$ will have larger inheritances, ceteris paribus. 
As stressed above, our goal is not to explain cross-sectional differences of the kind summarized in Table 4.1. Rather, we seek to explain why some of those who were not entrepreneurs in 1981 (those in column 3) made the transition into entrepreneurship.

Summary statistics relating to transitions to entrepreneurship and the attributes of the resulting new firms are reported in Table 4.2. The figures indicate that 11 percent of wage-earners made the transition to entrepreneurship between 1981 and 1985. For a crude comparison to previously reported annual transition rates, we divide this figure by four to obtain 2.75 percent, which is higher than the 1.9 percent transition rate from 1984 to 1985 in the SIPP data reported by Meyer [1990]. This is not surprising, given that our sample is older than the population as a whole, and previous studies have generally shown that the probability of a transition into self-employment increases with age. As an additional check on the data, we computed the 1981-85 transition rate to Schedule C for a sample drawn from all tax returns, not just those of donees. The rate was 6.8 percent. Dividing by four gives us 1.7 percent, which is essentially the same as the SIPP figure. Thus, at least on an aggregate basis, our tax return-based criterion for entrepreneurship does not differ markedly from that used in previous studies.

Table 4.2 indicates that the proportion who became entrepreneurs and established enterprises with some depreciable assets was 4.5 percent, considerably smaller than the 11 percent who became entrepreneurs. Depreciable assets in the new firms are computed as the lesser of the depreciation deduction reported on Schedule $C$ and $\$ 5,000$, plus 7.8 times the depreciation deduction in excess of $\$ 5,000$. The $\$ 5,000$ figure is the maximum that can be expensed; hence, up to this amount, it is reasonable to assume that every dollar of depreciation is equivalent to a dollar of capital investment. Capital expenditures above 
$\$ 5,000$ must be depreciated; the multiplier of 7.8 is consistent with the depreciation schedules in effect in $1985 .^{26}$ As Table 4.2 indicates, in 1985 the average level of depreciable assets (conditional on having positive assets) was about $\$ 15,000$. We stress, however, that this is the conditional mean; the figures in the table imply that only 41 percent of the new enterprises had any depreciable assets at all. The absence of capital from a substantial proportion of new enterprises is consistent with the results from Meyer's [1990, p. 15] analysis of SIPP data. He examined the portfolios of people who made the transition from salary work to self-employment between 1984 and 1985, and found that 56 percent of them reported no change in business equity upon entering self-employment. Similarly, Meyer noted that about 60 percent of new enterprises in the Characteristics of Business Owners survey report zero equity capital. As suggested in Section 2 above, one must regard with skepticism the assumption that new entrepreneurial enterprises must have positive amounts of capital.

The remainder of Table 4.2 is devoted to the interest expenses of the entrepreneurs. There are several ways that one can approach the measurement of this variable. One is to look at interest deductions taken on Schedule C. As indicated in the table, only 0.52 percent of the individuals in our sample became entrepreneurs and reported interest deductions on Schedule C. Together with the first figure in the column, this implies that fewer than five percent of new entrepreneurial enterprises reported any interest deductions. Conditional on listing an interest expense on Schedule C, the average size is $\$ 2,153$. However, in this context it is important to note that taxpayers can deduct interest on Schedules other than $\mathrm{C}$. In particular, Schedule A contains a line for deducting nonmortgage interest expenses. This observation is significant because money is fungible--there is no way to tell which borrowing 
is "for" the entrepreneurial enterprise. Another approach, then, is to measure interest as Schedule $\mathrm{C}$ interest plus nonmortgage interest from Schedule A. The last two lines of the table indicate that 7.7 percent of the new entrepreneurial enterprises had interest deductions on Schedule $\mathrm{C}$ and/or nonmortgage interest deductions on Schedule $\mathrm{A}$, and the conditional mean was $\$ 3,308$. Clearly, neither approach is ideal--Schedule $\mathrm{C}$ alone is probably too

restrictive, while Schedule C plus Schedule A probably includes too much. ${ }^{27}$ We therefore do the empirical analysis using both approaches, with the hope that the two admittedly imperfect measures will yield consistent implications for the impact of inheritance on interest expense.

\subsection{Econometric Issues}

Our goal is to develop an econometric framework for analyzing the three aspects of entrepreneurship highlighted by our theory: the transition to sole-proprietorship, the demand for depreciable assets, and the amount of borrowing to finance the new firm.

As indicated in Section 3, the probability that an individual makes the transition to sole-proprietorship depends upon the combined stochastic effects of $\theta_{i}$ and $w_{i}$, as well as the observed assets and personal characteristics (see relationship (3.14)). Assuming that the distribution of the resulting error term is normal yields a probit model of entrepreneurial choice.

Tuming now to the demand for capital, equation (3.8) indicates that the amount of capital depends on the levels of personal assets $\left(A_{i}\right)$ and (unobserved) entrepreneurial ability $\left(\theta_{i}\right)$. Examination of expressions (3.14) and (3.7) suggests that the probability of becoming a sole proprietor and having positive depreciable assets depends upon a stochastic component 
that reflects the joint influence of $w_{i}$ and $\theta_{i}$. Thus, the error term in the probit equation for the transition process will be correlated with the error term in the capital demand equation due to the common presence of $\theta_{i}$. Accordingly, to obtain consistent estimates, we must correct for the sample selection problem that arises because not all new firms have depreciable assets. We employ Heckman's [1976] two-stage process. The probit equation is estimated in the first stage, and in the second stage, the capital demand equation (augmented by the inverse Mills ratio) is estimated by ordinary least squares with the required correction of the standard errors. Econometric analysis of the amount of interest expense is handled symmetrically. It depends on the levels of personal assets, but is estimated in conjunction with a probit equation for the probability of becoming a sole proprietor and having positive interest expense.

\section{5. $\quad$ RESULTS}

To begin, we report the probit results for the transition into entrepreneurship, which are shown in column (1) of Table 5.1. Age, marital status, and number of children are statistically significant at conventional levels. Their coefficients suggest that the probability of becoming an entrepreneur increases with age until about 30 and then declines, increases with marriage, and decreases with the number of children. ${ }^{28}$ The only other significant coefficient is on DNONLIQ (the dichotomous variable that takes a value of one if the estate includes nonliquid assets), whose positive sign indicates that the likelihood of becoming a sole proprietor increases if an individual's inheritance includes a business. In general, then, our variables do not do a very good job of explaining who becomes an entrepreneur. 
Importantly, none of the variables characterizing the individual's asset position, including the size of the inheritance, appears to influence the entrepreneurial decision. In particular, the coefficient of the inheritance variable is statistically insignificant and of small quantitative importance. To see the latter, note that increasing the level of inheritance by $\$ 100,000$ raises the probability (evaluated at the sample means) of making the transition to sole-proprietorship by only 0.0027 .29

Do these results imply that liquidity considerations have no influence on entrepreneurial decision-making? The theory developed in Section 3 stresses that to capture the full effect we must also look at the capital purchases of entrepreneurs. Columns (2) and (3) present the results of this investigation. Recall from the discussion above that we must employ a probit equation to correct for the self-selection problems associated with the capital demand equation. Column (2) contains the probit results for the transition into an entrepreneurial enterprise that has depreciable assets. The results are quite similar to those in column (1). With the exception of age, none of the variables is significantly related to the probability of making such a transition. As in column (1), the inheritance variable has a small quantitative effect, with an increase in inheritance of $\$ 100,000$ raising the transition probability by a minuscule 0.000012 .

The next step in the analysis is in column (3), which examines the level of depreciable assets, conditional on the level being positive. As suggested by expressions (3.9) and (3.10), we may conclude that liquidity concerns are irrelevant only if the amount of capital does not depend on the asset variables. The estimates indicate that the size of the inheritance has a positive effect on the amount of capital in the new enterprise, and the coefficient exceeds its estimated standard error by a factor of about $2.5 .^{30}$ The implied marginal propensity to 
purchase assets out of inheritances, conditional on having positive assets, is only 5.9 percent. However, because capital investment in new enterprises tends to be small, this represents a substantial percentage increase in the level of assets. The elasticity, conditional on making the transition to a sole-proprietorship with depreciable capital, is about 0.45 when evaluated at the means of the variables. The unconditional elasticity, in contrast, is a much smaller 0.18 . The difference reflects, in part, the fact that variations in the size of inheritance have little effect on the transition probability.

We next tum to the results on interest expense contained in the final two columns of Table 5.1. As stressed earlier, it is not clear which measure of interest expenses is preferable. To conserve space, in Table 5.1 we report only the results for the sum of interest on Schedule C and nonmortgage interest on Schedule A. With respect to the probit for the transition to a new firm that has interest deductions, the signs and magnitudes of the demographic variables are similar to those in the second column. The inheritance variable is statistically significant, and its coefficient implies that an increase of $\$ 100,000$ in inheritance raises the probability of making the transition to having a Schedule C with interest deductions by 0.0026 .

Tuming now to the fifth column, the effect of inheritance on the amount of interest is positive and precisely estimated. As shown in the model in Section 3, this is consistent with the presence of liquidity constraints. (See equation (3.11).) The implied conditional elasticity evaluated at the means is $\mathbf{0 . 2 6}$. Note also that the coefficient on inheritance is smaller than the corresponding coefficient in the capital demand equation (column 3), which is also consistent with the theoretical predictions for liquidity-constrained firms.

As noted earlier, we repeated the analysis in the last two columns using Schedule C interest alone' as the left-hand-side variable. This definition provides a much smaller sample 
for analyzing the level of interest deductions -- only 31 returns reported them on Schedule C. Not surprisingly, the coefficients in this equation (available on request) are estimated imprecisely. Qualitatively, however, the results are quite similar to those reported in Table 5.1. In particular, the point estimate on inheritance is 5,257 , which is positive and less than the corresponding coefficient in column (2). However, given that the associated t-statistic is only 1.02 , one should not make too much of this result.

What picture emerges from Table 5.1? We conclude that liquidity effects have little to do with the transition to entrepreneurship, per se. Indeed, movements into soleproprietorships are not well predicted by the entire set of variables at our disposal. On the other hand, liquidity effects appear to have a substantial effect on the scale of capital investment, conditional on becoming an entrepreneur. The evidence on the effect of liquidity on the amount of borrowing by new entrepreneurs is necessarily murky, because it is not clear which interest deductions on the tax return are associated with borrowing for the entrepreneurial enterprise. Our tentative finding is that interest payments increase with the size of the inheritance, which is also consistent with the presence of liquidity constraints.

Alternative Specifications. We tested a number of variations on the specifications in Table 5.1 to assess the robustness of the results. As noted above, one potentially troubling possibility is that some of the people who file Schedule $C$ are not "serious" entrepreneurs. We therefore re-estimated the models defining an entrepreneur as someone with a Schedule C reporting gross receipts in excess of $\$ 1,000$. Imposing this definition lowers the proportion of individuals making the transition to entrepreneurship substantially -- from the 11.1 percent reported in Table 4.2 to 8.3 percent. Nevertheless, the new definition had little impact on the results. For example, like its counterpart in column (1) of Table 5.1, the estimated coefficient 
on inheritance in the transition equation $(0.0620$, with a standard error of 0.124$)$ is quantitatively small and statistically insignificant. ${ }^{31}$ In the same spirit, we examined the transitions of individuals who began filing a Schedule C in 1985 and simultaneously experienced a decrease in wage and salary income of at least 25 percent between 1981 and 1985. Under this definition, 4.4 percent of the sample are classified as making the transition to entrepreneurship. Again, there is not much impact on the results. The coefficient of the inheritance variable remains statistically insignificant at conventional levels and its quantitative impact is comparable to that in the basic results reported above.

Of course, an inappropriate definition of entrepreneurship is not the only possible source of specification error. One could argue, for example, that liquidity constraints are not very important for people who initially have high income or wealth, so that pooling them with other people will obscure the possible effects of liquidity constraints. We therefore estimated the various models separately for people with liquid assets greater than $\$ 70,000$ and for those with less than $\$ 70,000$. One cannot reject the null hypothesis that the coefficients are the same in each equation. (For example, in the case of the transition to Schedule $\mathrm{C}$ probit equation, the chi-square test statistic is 16.6 with 14 degrees of freedom, while the critical value for the 95 percent significance level is 23.7.) Similarly, we divided the sample into relatively low income $(\mathrm{AGI}<\$ 50,000)$ and high income $(\mathrm{AGI} \geq \$ 50,000)$ groups, and estimated the models using each subsample. Again, no significant differences were isolated. (In the transition to Schedule C probit, the chi-square statistic associated with the null hypothesis of identical coefficients was 8.2.) 
In short, the substantive results in Table 5.1 do not appear to be sensitive to reasonable variations in the criteria for classification as an entrepreneur, or to differences in specification that allow for asset and income levels to interact with the other variables.

\section{SUMMARY}

This paper analyzes the role of liquidity constraints in the formation of new entrepreneurial enterprises. The basic empirical strategy is to determine whether the probability of becoming an entrepreneur, and the conditional amounts of depreciable assets and interest deductions, are affected by an individual's level of assets, ceteris paribus. If so, liquidity constraints are likely to be present. For such a research strategy to be successful, one needs a measure of asset variation that is both precisely measured and exogenous to the entrepreneurial decision. Our data are uniquely well-suited for these purposes. The sample consists of the 1981 and 1985 federal tax retums of a group of people who received inheritances in 1982 and 1983, along with information on the size of those inheritances from a matched set of bequest tax returns. Hence, we can examine how the exogenous receipt of capital affects the decision to become an entrepreneur and important financial characteristics of new entrepreneurial enterprises. This is as close to a natural experiment as one can get in a subject like this one.

Straightforward tabulations of the data indicate that a majority of new enterprises have no depreciable capital assets. Consequently, our theoretical model explicitly allows for the possibility that entrepreneurs can produce positive output with zero capital, and hence, to the extent that liquidity constraints are present, their effect may be on the amount of capital acquired by the firm rather than on the probability of establishing a new enterprise per se. 
Indeed, our results suggest that the size of the inheritance has little effect on the probability of becoming an entrepreneur, but that conditional on becoming an entrepreneur, the size of the inheritance has a statistically significant and quantitatively important effect on the amount of capital employed. The conditional elasticity is 0.45 . Thus, liquidity constraints matter, but not in the fashion suggested in some earlier investigations. Our finding that soleproprietorships are undercapitalized is consistent with the results of Fazzari, Hubbard and Petersen [1988], which suggest that even corporations are constrained in capital markets.

A natural question in light of these findings is whether a new enterprise's amount of capital affects its ultimate success. Do new enterprises with substantial capital survive longer, eam higher profits, etc.? If so, then liquidity constraints might affect the long-run number of entrepreneurial enterprises, working indirectly through the initial level of capital. This is an important topic for future research. ${ }^{32}$ 
TABLE 4.1

SAMPLE MEANS IN 1981*

\section{Variable}

AGE

(age in 1981)

AGE66

( $=1$ if 65 or over)

AGE?

(=1 if age unknown)

MARRIED

(=1 if married)

CHILDREN

(= number of children under 18 )

W\&S $\times 10^{-6}$

(wage and salary income)

LIQASSTS $\times 10^{-6}$

(liquid assets)

HOME

( $=1$ if homeowner)

INH $\times 10^{-6}$

(inheritance)

DNONLIQ

$(=1$ if decedem's estate includes

nonliquid assets)

DC

( $=1$ if deceden filed a Schedule C)

DC $\times$ CHLD

( $=1$ if $D C=1$ and the donee is a child of the decedent)

N

(number of observations)
(1)

(2)

(3)

Entire Sample

41.5

(19.9)

0.194

(0.396)

0.0465

(0.210)

0.541

(0.498)

0.684

(1.10)

0.0191

(0.0256)

0.144

(0.445)

0.471

(0.499)

0.119

(0.200)

0.306

(0.461)

0.117

(0.321)

0.0421

(0.200)

7,036
Schedule C

43.3

(15.4)

0.147

(0.355)

0.0222

(0.147)

0.731

(0.444)

0.956

(1.18)

0.0168

(0.0295)

0.139

(0.353)

0.621

(0.485)

0.131

(0.201)

0.316

(0.465)

0.142

(0.349)

0.0604

(0.238)

1,126
No Schedule C

41.1

(20.6)

0.203

(0.402)

0.0511

(0.220)

0.505

(0.500)

0.632

(1.08)

0.0195

$(0.0248)$

0.146

$(0.460)$

0.443

(0.497)

0.117

(0.200)

0.304

$(0.460)$

0.112

(0.315)

0.0384

$(0.192)$

"Numbers in parentheses are standard deviations. 
TABLE 4.2

TRANSITIONS TO ENTREPRENEURSHIP AND RELATED DECISIONS*

Proportion with Schedule C reported in 1985 but not in 1981

Proportion with Schedule C including depreciable assets $\quad 0.0450$

reported in 1985 but no Schedule $C$ in 1981

Depreciable assets in 1985 (conditional on depreciable assets

15,047 being positive)

Proportion with Schedule C interest expense in 1985, but no Schedule C in 1981

Schedule $\mathrm{C}$ interest deductions in 1985 (conditional on interest deductions being positive)

Proportion with Schedule C interest expense or Schedule A nonmortgage interest expense in 1985, but no Schedule $C$ in 1981

Schedule $C$ and Schedule A nonmortgage interest deductions (conditional on interest deductions being positive)

Numbers in parentheses are standard deviations. 
TABLE 5.1*

PARAMETER ESTIMATES

\begin{tabular}{|c|c|c|c|c|c|}
\hline Variable & $\begin{array}{c}\text { Probit: } \\
\text { Schedule C }\end{array}$ & $\begin{array}{c}\text { Probit: } \\
\text { Schedule C } \\
\text { w/ Depreciable } \\
\text { Assets }\end{array}$ & $\begin{array}{c}\text { Level of } \\
\text { Depreciable } \\
\text { Assets }\end{array}$ & $\begin{array}{c}\text { Probit: } \\
\text { Schedule C plus A } \\
\text { Interest }\end{array}$ & $\begin{array}{l}\text { Level of } \\
\text { Interest }\end{array}$ \\
\hline Constant & $\begin{array}{c}-1.769 \\
(0.1846)\end{array}$ & $\begin{array}{c}-2.630 \\
(0.2918)\end{array}$ & $\begin{array}{c}-23,399 \\
(37,130)\end{array}$ & $\begin{array}{c}-2.241 \\
(0.237)\end{array}$ & $\begin{array}{c}3,642 \\
(2,251)\end{array}$ \\
\hline Age & $\begin{array}{c}0.0444 \\
(0.01085)\end{array}$ & $\begin{array}{c}0.9711 \\
(0.0174)\end{array}$ & -- & $\begin{array}{c}0.05134 \\
(0.01393)\end{array}$ & -. \\
\hline $\mathrm{Age}^{2} \times 10^{-3}$ & $\begin{array}{c}-0.7434 \\
(0.1398)\end{array}$ & $\begin{array}{c}-1.1225 \\
(0.2294)\end{array}$ & -- & $\begin{array}{c}-0.8638 \\
(0.1800)\end{array}$ & .. \\
\hline Age66 & $\begin{array}{c}0.0606 \\
(0.1432)\end{array}$ & $\begin{array}{c}-0.4438 \\
(0.3555)\end{array}$ & -- & $\begin{array}{c}-0.004168 \\
(0.1785)\end{array}$ & -- \\
\hline Age? & $\begin{array}{c}0.3252 \\
(0.2144)\end{array}$ & $\begin{array}{c}0.6474 \\
(0.3305)\end{array}$ & -- & $\begin{array}{c}0.3978 \\
(0.2718)\end{array}$ & -- \\
\hline Married & $\begin{array}{c}0.1967 \\
(0.0594)\end{array}$ & $\begin{array}{c}0.0997 \\
(0.0813)\end{array}$ & -- & $\begin{array}{c}0.2289 \\
(0.06800)\end{array}$ & -- \\
\hline Children & $\begin{array}{c}-0.05841 \\
(0.02453)\end{array}$ & $\begin{array}{c}-0.0451 \\
(0.0323)\end{array}$ & -- & $\begin{array}{c}-0.06447 \\
(0.02665)\end{array}$ & -- \\
\hline W\&S & $\begin{array}{c}1.193 \\
(1.052)\end{array}$ & $\begin{array}{l}-0.4036 \\
(1.526)\end{array}$ & -- & $\begin{array}{c}1.571 \\
(1.104)\end{array}$ & - \\
\hline DC & $\begin{array}{c}0.05000 \\
(0.08615)\end{array}$ & $\begin{array}{c}0.1143 \\
(0.1127)\end{array}$ & -- & $\begin{array}{l}0.002441 \\
(0.1020)\end{array}$ & -- \\
\hline DC x Child & $\begin{array}{c}0.1383 \\
(0.1277)\end{array}$ & $\begin{array}{c}0.0833 \\
(0.1622)\end{array}$ &.- & $\begin{array}{c}0.1731 \\
(0.1441)\end{array}$ & -- \\
\hline LIQASSTS & $\begin{array}{c}-0.1394 \\
(0.0854)\end{array}$ & $\begin{array}{c}-0.0207 \\
(0.09565)\end{array}$ & $\begin{array}{c}-10,437 \\
(18,442)\end{array}$ & $\begin{array}{c}-0.1030 \\
(0.08806)\end{array}$ & $\begin{array}{c}2,426 \\
(1,265)\end{array}$ \\
\hline HOME & $\begin{array}{c}0.00930 \\
(0.05716)\end{array}$ & $\begin{array}{c}0.1048 \\
(0.0778)\end{array}$ & $\begin{array}{c}1,309 \\
(7,176)\end{array}$ & $\begin{array}{c}0.2796 \\
(0.06507)\end{array}$ & $\begin{array}{c}168.1 \\
(571.6)\end{array}$ \\
\hline INH & $\begin{array}{c}0.1695 \\
(0.1150)\end{array}$ & $\begin{array}{c}0.00239 \\
(0.1638)\end{array}$ & $\begin{array}{c}59,401 \\
(23,822)\end{array}$ & $\begin{array}{c}0.2610 \\
(0.1227)\end{array}$ & $\begin{array}{c}6,245 \\
(1,286)\end{array}$ \\
\hline DNONLIQ & $\begin{array}{c}0.1071 \\
(0.0483)\end{array}$ & $\begin{array}{c}0.1088 \\
(0.0642)\end{array}$ & $\begin{array}{c}1,219 \\
(7,622)\end{array}$ & $\begin{array}{c}0.1407 \\
(0.05423)\end{array}$ & $\begin{array}{c}-1,063 \\
(542.0)\end{array}$ \\
\hline$\lambda$ & $\cdots$ & -- & $\begin{array}{c}16,073 \\
(18,518)\end{array}$ & -- & $\begin{array}{r}-656.4 \\
(1,149)\end{array}$ \\
\hline Loglikelihood & $-1,923$ & -995 & $-3,295$ & $-1,459$ & $-4,548$ \\
\hline $\mathbf{N}$ & 5,910 & 5,910 & 266 & 5,910 & 455 \\
\hline
\end{tabular}

"Numbers in parentheses are standard errors. $\lambda$ is the coefficient on the inverse Mills ratio. Other variables are defined in Table 4.1. 
1. Hearings before the Subcommittee on Entrepreneurship and Special Problems Facing Small Business of the Committee on Small Business. United States Senate, S. Hrg. 99 677, U.S. Govermment Printing Office, Washington, D.C., 1986.

2. See, for example, Stiglitz and Weiss [1981].

3. For a comprehensive summary of the empirical literature, see Blanchflower and Meyer [1990].

4. A number of studies estimate cross-sectional equations without any assets variables, principally because of data constraints. See, for example, Fuchs [1982] and Rees and Shah [1986].

5. Blanchflower and Meyer [1991] examined the sub-sample of the SIPP data consisting only of young people, and reported that assets are a statistically significant determinant of the transition probability. However, one cannot determine its quantitative importance, given the data they report. Blanchflower and Meyer also examined transitions to self-employment in Australia. However, the Australian data set contains no infornation on assets, and hence cannot be used to address the liquidity constraint issue.

6. If the marginal utility of income is not constant, then increases in wealth may increase the propensity to become an entrepreneur by reducing risk aversion, independent of borrowing constraints. Evans and Jovanovic [1989] offer evidence that such an effect is not operative. Their estimates indicate that the effect of initial assets on entrepreneurial eamings diminishes over time. They point out that if assets were proxying for tastes for entrepreneurship, there would be no reason for the effect to diminish over time.

7. Our assumptions on the stochastic properties of $w_{i}, \theta_{i}$, and $\varepsilon$ follow those of Evans and Jovanovic [1989].

8. Interestingly, some theoretical treatments of the entrepreneurship decision predict that new enterprises will have zero capital. For example, Shorrocks [1988] provides a model in which the first stage of an entrepreneurial enterprise requires taking "lowbudget risks" that involve no capital.

9. Blanchflower and Oswald [1990] assumed that all agents face an exogenously given probability of not being able to borrow at all.

10. Recall that the value of $\theta_{i}$, the individual's ability as an entrepreneur, is revealed after the individual chooses to be an entrepreneur, and is thus a parameter for the purposes of the capital demand decision. 
11. The absence of the cost of capital from equation (3.8) is a consequence of the assumption that $r$ is constant across firms. As in the case of Evans and Jovanovic [1989] and others, our data preclude identifying differences in $r$ across entrepreneurs.

12. We present the entrepreneur's problem as a two-step process for expositional purposes only. In practice, these decisions are being made simultaneously.

13. This is the assumption made by Rees and Shah [1986]. Evans and Jovanovic [1989] compare expected real incomes rather than utilities; this distinction is not an important one in this context. In principle, one could generalize the model to allow for the possibility of spending some time in each of the two modes. This would complicate the inodel without adding any insights that are important for our present purposes.

14. We experimented with a term that interacted eamings and the dichotomous marriage variable, with the hope of isolating the opportunity cost effect for single eamers. This variable had no effect on the substantive results presented below.

15. There are no data on receipts of tax-exempt interest.

16. The Characteristics of Business Owners data set created by the U.S. Census Bureau also uses a tax-based definition of entrepreneurship. (See Holmes and Schmitz [1991].) However, these data characterize members of partnerships and Subchapter $S$ corporations (from Schedule E) as well as sole proprietors as "entrepreneurs." The inclusion of a Schedule $E$ on a tax return may be more reflective of tax shelter activity than entrepreneurship. In the context of this study, a practical advantage of a Schedule C criterion is that, unlike Schedule E, it provides information that can be used to estimate the enterprise's capital stock.

17. This figure includes "business services" (advertising, management consulting, public relations, computer services, etc.) and "accounting and bookkeeping services."

18. Further complications result from using annual data. A "serious" entrepreneur who makes the transition late in the year is likely to resemble a full-year, but "non-serious," entrepreneur.

19. Blanchflower and Oswald [1990] included a gifts and inheritances variable in their cross-sectional analysis of the incidence of self-employment among young British males. It is not clear whether this variable is exogenous. The Blanchflower-Oswald sample, taken from the National Child Development Study in the United Kingdom, consists entirely of 23-year olds. In the United States, the average age for receiving an inheritance is considerably higher, about 41.5. (See Gale and Scholz [1991].) Assuming a comparable age at inheritance in the U.K., a substantial portion of the transfers in the Blanchflower-Oswald data are probably gifts, and these gifts might have been made specifically to help the donees in starting businesses. We are grateful to Bruce Meyer for pointing this out to us. 
20. A potential problem is that an individual may have become a sole-proprietor in (say) 1984 and then gone back to wage and salary employment in 1985 . While we doubt that such a phenomenon is important enough to bias our results, it does suggest that it would be useful in future research to trace the year-by-year histories of new enterprises, if the appropriate data become available. In this context, it is interesting to note that in their analysis of Australian data, Blanchflower and Meyer [1991] reported that the results from examining transitions over two- and three-year periods were essentially the same as those found for one-year transitions.

21. Excluded from the sample are retums that reported partnership or rental income. Such entities are commonly tax shelters; hence, one cannot use the (often negative) income flows to impute the underlying value of assets.

22. Recall, however, that the definition of "entrepreneur" differs.

23. The age variable refers to the age of the beneficiary. On a joint return, the beneficiary may not be the person who becomes an entrepreneur. The possible measurement error is attenuated to the extent that spouses' ages are correlated. On single retums, the age of the relevant agent is measured without error.

24. To obtain a more definitive basis for comparisons with previous cross-sectional analyses, we used the 1981 data to estimate a probit equation for the presence of a Schedule $C$ on the tax retum, using as explanatory variables age, marital status, and number of children. The results are consistent with the impressions from Table 5.1 and the results from earlier studies: the probability of being an entrepreneur increases with age, increases with being married, and increases with the number of children.

25. Of the 1,126 retums containing a Schedule $C, 387$ reported no wages and salaries at all.

26. Specifically, we used the Statistics of Income sole-proprietorship file for 1985 to compute the average cost to deduction ratio for each type of property, and then took a weighted average across types of property.

27. An even more inclusive measure would take into account mortgages, some fraction of which might serve to finance a business. In practice, we believe that mortgage loans are driven primarily by housing decisions, and including mortgage interest is unlikely to add useful information on the extent of borrowing for business activity.

28. The pattem of a positive linear term and a negative quadratic term in age is consistent with Meyer's [1990] logit analysis of the transition to self-employment in the 1984 wave of the SIPP data. Meyer also finds a positive sign for the marriage variable and a negative effect for the number of children.

29. The probability rises from 0.08715 to 0.08987 . Note that dividing by four gives the effect on transitions each year. Our estimate, 0.0007 , is of comparable magnitude to that estimated by Meyer [1990]. 
30. The liquid assets variable continues to be statistically insignificant. As emphasized earlier, this variable is likely to be subject to substantial mismeasurement.

31. The complete set of results is available upon request to the authors.

32. Some interesting preliminary evidence along these lines is provided by Holmes and Schmitz [1991]. Their tabulations from the Characteristics of Business Owners Survey suggest that only two percent of entrepreneurs whose businesses were discontinued list "inability to obtain required financing" as a reason. 


\section{References}

Avery, R., G. Elliehausen, and A. Kennickell, "Measuring Wealth with Survey Data: An Evaluation of the 1983 Survey of Consumer Finances," The Review of Income and Wealth, December 1988, pp. 339-370.

Blau, F. and D. Graham, "Black-White Differences in Wealth and Asset Composition," Quarterly Journal of Economics, 1990, pp. 321-339.

Blanchflower, D. and A. Oswald, "What Makes an Entrepreneur?" mimeo, 1990.

Blanchflower, D. and B. Meyer, "A Longitudinal Analysis of Young Entrepreneurs in Australia and the United States," National Bureau of Economic Research, Working Paper No. 3746, 1991.

Evans, D. and L. Leighton, "Some Empirical Aspects of Entrepreneurship," American Economic Review, 1989, pp. 519-535.

Evans, D. and B. Jovanovic, "An Estimated Model of Entrepreneurial Choice Under Liquidity Constraints," Journal of Political Economy, 1989, pp. 808-827.

Fazzari, S.M., R.G. Hubbard and B.C. Petersen, "Financing Constraints and Corporate Investment," Brookings Papers on Economic Activity, No. 1, 1988, pp. 141-195.

Fuchs, V., "Self-Employment and Labor-Force Participation of Older Males," Journal of Human Resources, 1982, pp. 339-357.

Gale, W. and K. Scholz, "Intergenerational Transfers and the Accumulation of Wealth," University of Wisconsin, mimeo, 1991.

Heckman, J., "The Common Structure of Statistical Models of Truncation, Sample Selection, and Limited Dependent Variables and a Simple Estimator for Such Models," Annals of Economic and Social Measurement, 1976, pp. 475-492.

Holmes, T.J. and J.A. Schmitz, "Measuring Small Business Dynamics When Owners and Their Businesses Can Be Separately Identified," Dartmouth College, mimeo, 1991.

Lentz, B.F. and D. N. Laband, "Entrepreneurial Success and Occupational Inheritance Among Proprietors," Canadian Joumal of Economics, XXIII, August 1990, pp. 563-579.

Menchik, P.L., "Unequal Estate Division: Is it Altruism, Reverse Bequests, or Simply Noise?" in Kessler, D. and A. Masson (eds.), Modeling the Accumulation and Distribution of Wealth, Oxford: Clarendon Press, 1988, pp. 105-119 . 
Meyer, B., "Why Are There So Few Black Entrepreneurs?" National Bureau of Economic Research, Working Paper No. 3537, 1990.

Rees, H. and A. Shah, "An Empirical Analysis of Self-Employment in the U.K.," Journal of Applied Econometrics, 1986, pp. 95-108.

Schumpeter, J., Capitalism, Socialism and Democracy, New York: Harper and Row Publications, 1942.

Shorrocks, A.F., "Wealth Holdings and Entrepreneurial Activity" in Kessler, D. and A. Masson (eds.) Modeling the Accumulation and Distribution of Wealth, Oxford: Clarendon Press, 1988, pp. 241-258.

Skinner, J. and D. Feenberg, "The Impact of the 1986 Tax Refonn Act on Personal Saving," National Bureau of Economic Research, Working Paper No. 3257, 1990.

Stiglitz, J. and A. Weiss, "Credit Rationing in Markets with Imperfect Information," American Economic Review, June 1981, pp. 393-410. 